\title{
USE OF MORINGA LEAVES (MORINGA OLEIFERA) IN FATTENING LAMBS RATIONS
}

\author{
Sobhy M. Allam; G.E. Aboul-Fotouh; G.M. El-Garhy and Ola Gamal \\ Animal Production Department, Faculty of Agriculture, Fayoum University, Egypt.
}

\section{SUMMARY}

\begin{abstract}
$\mathrm{T}$ he effect of moringa leaves (Moringa oleifera) on fattening lambs, digestibility, feeding values, feed conversion, growth performance and economical evaluation were studied. The moringa leaves was included at a rate of $0,7.5,15$ and $30 \%$ of the tested rations replacing soybean meal forming four dietary treatments. The control ration consisted of $75 \%$ concentrate feed mixture $+25 \%$ wheat straw. Twenty lambs with average live body weight $45 \pm 1.0 \mathrm{~kg}$ at 10 months of age were used for 90 days feeding period. Five animals were allotted per treatment. Results revealed that moringa leaves containing high of ether extract, crude protein and nitrogen free extract $(5.8,16.5$ and 52.7), respectively, but containing low of crude fiber, acid detergent fiber and nutrient detergent fiber (13.1, 20.0 and 30.3), respectively. Digestibility of all nutrients were non-significant except that ether extract (EE). Nutritive values tended to decrease as the level of moringa leaves increased. While DM intake and feed conversion tended to increase as the level of moringa leaves increased in the ration. Significant effects of blood analysis were obtained at liver and kidney function, when the level of moringa leaves increased in the rations. Economical evaluation was in favor of the $15 \%$ and $30 \%$ level supplementation regarding relative percentage of net revenue and relative percentage of cost of feed consumed. In conclusion, moringa leaves could be used economically and successfully for feeding lambs.
\end{abstract}

Keywords: Fattening lambs, moringa leaves, digestibilities, intake, growth performance and economical evaluation.

\section{INTRODUCTION}

One of the major factors limiting the productivity of small ruminants in developing countries is the over-dependence on low digestibility feeds which at certain periods of the year cannot meet even the maintenance requirements of these animals. In recent years there has been a growing interest in many countries to identify potentially important feed sources among shrubs and trees for inclusion in the ruminant diet to provide green fodder that is high in protein to supplement the available low protein forage. This has been recognized as one of the most effective means of improving animal performance in smallholder livestock production (Blair 1989). The availability and price of concentrates, in particular of protein sources, are a serious problem for animal producers, especially for small farms stakeholders. Consequently, there is a need for alternative ingredients with high protein content and balanced amino acids profile, and with a suitable cost. Plants leaf meal, forage trees, saltbush and shrubs are good and cheap sources of protein (Mendieta- Araica et al., 2011; Alsersy et al., 2015; Salem et al., 2006 ،2015 and Kholif et al., 2015). Moringa oleifera is a well-known tree in West Africa especially in semi-arid areas where it is often cultivated as a living fence around people's gardens and consumed in various forms as food. Leaves of the tree are noted for high content of crude protein, essential vitamins, minerals and amino acids (Makkar and Becker 1997; Gidamis et al. 2003). Moringa oleifera is a widespread, drought tolerant tree with a high DM yield in the tropics (Reyes-Sánchez et al., 2006), the potential for using moringa as animal feed is still underappreciated. It is a tree with a high CP content, varying from 179 to $268 \mathrm{~g} \mathrm{~kg} \mathrm{DM}^{-1}$ (Reyes- Sánchez et al., 2006; Mendieta-Araica et al., 2009). Due to this recent interest in moringa, feeding trials using fresh moringa have been performed with many types of animals such as pigs, goats and creole cows (Ly et al., 2001; Aregheore, 2002; Reyes- Sánchez et al., 2006). The objective of this study was to evaluate the effect of replace soybean meal protein by Moringa oleifera protein to fattening lambs on the intake, digestibility, growth performance, and blood parameters. 


\section{MATERIALS AND METHODS}

The present study was carried out at experimental farm and laboratories of animal production department, faculty of agriculture, Fayoum University, Egypt. The tested rations $\left(\mathrm{R}_{1}, \mathrm{R}_{2}, \mathrm{R}_{3}\right.$ and $\left.\mathrm{R}_{4}\right)$ represent four dietary treatments that contain moringa leaves at levels of $0,7.5,15$ and $30 \%$ replaced with soybean meal, respectively, as presented in Table (1). The chemical compositions of ingredients as well as the tested rations are present in Table (2). Nutrient digestibility and feeding values were determined by chosen 3 lambs randomly from each group, using acid insoluble ash (AIA) technique of Van Keulen and Young (1977). Feeds and feces were sampled and the conventional analytical methods of A.O.A.C. (1990) were applied. Also, digestibility coefficient and feeding values of the tested rations were determined. Gross energy and digestible energy (DE) were calculated after Nehring and Haenlien (1973).

Feeding trials was conducted using $20 \mathrm{ram}$ lambs with an average age of 10 months and $45.0 \pm 1.0 \mathrm{~kg}$ live body weight. Animals were allotted in equal numbers to test the four rations ( 5 animals/each). The experimental duration extended for 90 days and the rations were fed to cover the nutritional requirements of fattening sheep according to N.R.C (1985). Rations were offered twice daily at 9.0 a.m. and 4.0 p.m. in equal portions. Fresh water was available and animals were healthy and under veterinary care. Lambs body weight was recorded biweekly before morning feeding. Daily gain, average feeding intake and feed conversion were determined.

Blood samples were collected from jagular vein in heparinzed tubes before feeding in the morning at the end of fattening lambs trial from each animal. Blood samples were centrifuged at $4500 \mathrm{round} / \mathrm{min}$. for $20 \mathrm{~min}$. to obtain blood serum. Serum total protein and albumin were estimated by calorimetric method as described by Cannon (1974), serum globulin was calculated, and serum glucose was measured calorimetrically according to Howanitz and Howanitz (1984).

Simple economical evaluation was calculated for the tested rations. The price of one $\mathrm{kg}$ live weight gain of sheep was 36 L.E. and the cost of one ton of moringa leaves, corn, wheat bran, soya bean meal, fed additive mixture and wheat straw were 1500, 2000, 1800, 4200, 2300 and 800 L.E, respectively. Complete randomize design was used for experimental rations. Data obtained were subjected to statistical analysis according to general linear models procedure adapted by SPSS (1997).

\section{RESULTS AND DISCUSSION}

\section{Nutritive evaluation:}

Moringa contained $28.91 \%$ DM, $16.52 \%$ CP, $5.78 \%$ EE, $11.14 \%$ Ash, $13.14 \%$ CF, 30.27\% NDF, $20.03 \%$ ADF, 5.4\% ADL, 10.78\% hemicelluloses, $14.63 \%$ cellulose and $1.81 \%$ tannins (Table 2). Regarding DM, OM, EE and NDF\%, the results obtaining by Kholif et al. (2015) may suggest the obtained results in this study. Data of NDF, ADF, ADL, hemicelluloses and cellulose were decreased slightly compared to Khayyal et al. (2015) which may reflect the differences of moringa parts samples that analyzed, but the same trend was found with Taninat. Comparing the four tested rations, their chemical composition was nearly similar expiate that CP. Table (3) showed insignificant effect on the digestibility coefficients regarding DM, OM, CP, CF and NFE in the presence of moringa leaves. The EE digestibility did show significant differences $(\mathrm{P} \leq 0.05)$ in the presence of moringa leaves. Khayyal et al. (2015) reported higher DM, OM, EE and NFE with lower CP and CF digestibilities than the obtained results of R4 (30\% moringa).Energy values of total digestible nutrients (TDN) and digestible energy (DE) of the tested rations in Table (3) had insignificant effect in moringa leaves containing rations, while digestible crude protein (DCP) was significantly affected $(\mathrm{P} \leq 0.05)$ of control ration compared with other rations. The results were in favour of $\mathrm{R}_{2}$ in general. These results are in agreement with those reported by Seshadri (2003), Khalafalla et al. (2010), Debela and Tolera (2013) and Teixeira et al.(2014) mentioned that the moringa leaves contain high levels of lipids and protein. Although moringa leaves contain considerable amounts of crude protein these are mostly insoluble and have low digestibility. Also, Mahmoud (2013) and Jelali and BenSalem (2014) concluded that daily and alternate distribution of moringa leaves had similar effect on digestibility and feeding value in sheep than soybean meal.

\section{Feed intake and growth performance:}

Data of Table (4) indicated that the lambs total gain and daily gain were affected significantly $(\mathrm{P} \leq$ $0.05)$ when moringa leaves was included at $15 \%\left(R_{3}\right)$ in the ration compared with other rations. However, daily crude protein intake and feed conversion were improved significantly $(\mathrm{P} \leq 0.05)$ when moringa 
leaves was included at $7.5 \%\left(\mathrm{R}_{2}\right)$ in the ration compared with other rations. These results are in accordance with those obtained by Aregheore (2002), Sarwatt et al. (2002), Ben Salem and Makkar (2009), Asaolu et al. (2012), Mahmoud (2013) found that rations contained moringa leaves improved growth performance and feed conversion.

\section{Blood parameters:}

Regarding blood parameters (Table 5) showed insignificant increase in fattening lamb's total protein, albumin and glucose as the time of treatment advanced. Meanwhile, the concentration of urea, AST and ALT were decreased significantly $(\mathrm{P}<0.05)$ as the time of treatment advanced. Such results were nearly similar to that obtained in growing lambs by Boyd (2011) and Mahmoud (2013). In the same time, the values of all blood parameters of all tested animals were within the normal range of healthy animals.

\section{Economical evaluation and conclusion:}

The presence of moringa leaves reduced the cost of consumed feed and improved the net revenue especially when added at $15 \%$ of ration (Table 6 ). The relative costs of feed consumed/head/period were $100,97.19,94.69$ and $87.32 \%$ for rations of $R_{1}, R_{2}, R_{3}$ and $R_{4}$ respectively. The corresponding values of relative percentage of net revenue were $100,56.45,171.83$ and $125.6 \%$. These results were in harmony with those of Jelali et al. (2014) who found that using moringa leaves in growing lambs decreased feed cost and increased the economic return. Also, Mahmoud (2013) found that the concentrate feed mixture could be replaced by moringa while improved animal performance and increased net return.

In conclusion the rations containing moringa leaves could be used economically and successfully for fattening lambs since it improved daily gain, feed efficiency and economic efficiency. On the other hand, soybean meal could be replaced by moringa leaves which could result in improving animal performance and increase the net revenue which represent a partial solution for the high price of soybean meal.

\section{REFERENCES}

Alsersy, H., Salem, A.Z.M., Borhami, B.E., Olivares, J., Gado, H.M., Mariezcurrena, M.D., Yacuot, M.H., Kholif, A.E., El-Adawy, M., Hernandez, S.R.(2015). Effect of Mediterranean saltbush (Atriplex halimus) ensilaging with two developed enzyme cocktails on feed intake, nutrient digestibility and ruminal fermentation in sheep. Anim. Sci. J, 86, 51-58.

AOAC (1990). Association of Official Analytical Chemists. Official methods of analysis. $13^{\text {th }}$ ed. Washington, D.C., USA.

Aregheore, E. (2002). Intake and digestibility of Moringa oleifera-batiki grass mixture by growing goats. Small Ruminant Res., 46:23.

Asaolu,V.; R. Binuomote; J. Akinlade; O. Aderinola and O. Oyelami (2012). Intake and Growth Performance of West African Dwarf Goats Fed Moringa oleifera, Gliricidia sepium and Leucaena leucocephala Dried Leaves as Supplements to Cassava Peels. Journal of Biology, Agriculture and Healthcare, 10:22-24.

Ben Salem, H. and H.P.S. Makkar (2009). Defatted Moringa oleifera seed meal as a feed additive for sheep. Animal Feed Science and Technology, 150:27.

Blair, G.J. (1989). The diversity of potential value of shrubs and tree fodders. In: C Devendra, ed., Shrubs and Tree Fodders for Farm Animals. Proceedings of a workshop in Denpasar, Indonesia.2.

Boyd, J.W. (2011). The interpretation of serum biochemistry test results in domestic animal, In: Veterinary Clinical Pathology, Merck Sharp\& Dohme Corp., a subsidiary of Merck \& Co., Inc.

Cannon, D.C. (1974). Assessment of total protein in clinical chemistery-row. Hagerstown, DM. 411.

Debela, E. and A. Tolera (2013). Nutritive value of botanical fractions of Moringa oleifera and Moringa stenopetala grown in the mid-Rift Valley of southern Ethiopia. Agroforest Syst, 87:1147.

Gidamis, A.B.; J.T. Panga; S.V. Sarwatt; B.E. Chove and N.B. Shayo (2003). Nutrients and antinutrient contents in raw and cooked leaves and mature pods of Moringa oleifera, Lam. Ecology of Food and Nutrition, 42:1.

Howanitz, P.J. and J.H. Howanitz (1984). Determination of blood glucose by enzymatic procedure in clinical diagnosis and management by laboratory methods $17^{\text {th }}$ ed., J.B. Henry, Ed., W.B. Saunders, Philadelphia. 168.

Jelali, R. and H. Ben Salem (2014). Daily and alternate day supplementation of Moringa oleifera leaf meal or soybean meal to lamb sreceiving oat hay. J. Livestock Science, 168:84.

Khalafalla, M. M.; E. Abdellatef; H.M. Dafalla; A.A. Nassrallah; K.M. Aboul-Enein; D.A. Lightfoot; F.E. El-Deeb and H.A. El-Deeb (2010). Active principle from Moringa oleifera Lam leaves effective against two leukemias and a hepatocarcinoma. African Journal of Biotechnology, 9:8467. 
Khayyal, Amany A., A.M. Shwerab, S.M. Khalel, A.A. Hassan and M.H. Yacout (2015). Influence of all or partial replacement of moringa from berseem on the productive performance of sheep. Egyptian J. Nutrition and Feeds, 18 (1): 21-34.

Kholif, A.E., G.A. Gouda, T.A. Morsy, A.Z.M. Salem, S. Lopez and A.M. Kholif (2015). Moringa oleifera leaf meal as a protein source in lactating goat's diets: Feed intake, digestibility, ruminal fermentation, milk yield and composition, and its fatty acids profile. Small Ruminant Research, 129, $129-137$.

Ly, J.; P. Samkol and T. Preston (2001). Nutritional evaluation of tropical leaves for pigs: pepsin/pancreatin digestibility of thirteen plan species. Livest. Res. Rural Dev., 13:5.

Mahmoud, A.E.M. (2013). Effect of feeding on Moringa oleifera stems on productive performance of growing lambs. Egyptian J. Nutrition and Feeds. 16(2):281.

Makkar, H.P.S. and K. Becker (1997). Nutrients and antiquality factors in different morphological parts of the Moringa oleifera tree. Journal of Agricultural Science, Cambridge, 128:311.

Mendieta-Araica, B.; E. Spörndly; N. Reyes-Sánchez; L. Norell and R. Spörndly (2009). Silage quality when Moringa oleifera is ensiled in mixtures with Elephant grass, sugar cane and molasses. Grass Forage Sci., 64:364.

NRC (1985). National Research Council. Nutrient requirements of sheep, National Academy of Science. Washington, D.C., USA.

Nehring, K. and G.F.W. Haenlien (1973). Feed evaluation and ration calculation based on net energy. J. Anim. Sci., 36:949.

Reyes-Sánchez, N.; E. Spörndly; I. Ledin (2006). Effect of feeding different levels of foliage of Moringa oleifera to creole dairy cows on intake, digestibility, milk production and composition. Livestock Sci., 101:24.

Sarwatt, S.V.; S.S. Kapange and A.M.V. Kakengi (2002). Substituting sunflower seed-cake with Moringa oleifera leaves as a supplemental goat feed in Tanzania. Agroforestry Systems. 56:241.

Seshadri, S.; V.S. Nambiar and Kanjero (2003). Digera arvensis and drumstick leaves (Moringa oleifera): nutrient profile and potential for human consumption. World Rev. Nutr. Diet., 91:41.

SPSS (1997). Statistical Package for Social Science release 8.0 copyright (c), SPSS INC., Chicago, USA.

Teixeira, E.M.; M.R. Carvalho; V.A. Neves; M.A. Silvaand and L. Arantes-Pereira (2014). Chemical characteristics and fractionation of proteins from Moringa oleifera Lam. Leaves. Food Chemistry, 147: 51.

Van Keulen, J. and B.A. Young (1977). Evaluation of acid insoluble ash as a natural marker in ruminant digestibility studies. J. Anim. Sci., 44: 282. 
Table (1). Formulation of the tested rations.

\begin{tabular}{lcccc}
\hline \multirow{2}{*}{ Ingredients } & \multicolumn{4}{c}{$\%$ on DM basis } \\
\cline { 2 - 5 } & $\mathrm{R}_{1}$ & $\mathrm{R}_{2}$ & $\mathrm{R}_{3}$ & $\mathrm{R}_{4}$ \\
\hline Yellow Corn & 55 & 55 & 55 & 55 \\
Wheat Bran (WB) & 22 & 19.5 & 17 & 12 \\
Soybean meal (SBM) & 20 & 15 & 10 & -- \\
Moringa & -- & 7.5 & 15 & 30 \\
Fed Additives* & 3 & 3 & 3 & 3 \\
\hline
\end{tabular}

*fed additives, composed of $2 \%$ limestone, $0.5 \%$ mineral and vitamins and $0.5 \%$ common salt.

Table (2). Chemical composition of ingredients and the tested rations on DM basis.

\begin{tabular}{|c|c|c|c|c|c|c|c|c|c|c|}
\hline \multirow[t]{2}{*}{ Item } & \multirow[t]{2}{*}{$\mathrm{DM} \%$} & \multicolumn{8}{|c|}{ Chemical composition, $\%$ on DM basis } & \multirow[t]{2}{*}{ GE, Mcal/kg } \\
\hline & & $\mathrm{OM}$ & $\mathrm{CP}$ & $\mathrm{EE}$ & $\mathrm{CF}$ & NFE & Ash & ADF & NDF & \\
\hline \multicolumn{11}{|c|}{ Ingredients: } \\
\hline $\mathrm{C}$ & 93.79 & 92.19 & 7.53 & 4.52 & 2.41 & 77.73 & 7.81 & 5.09 & 13.20 & \\
\hline WB & 94.10 & 89.63 & 12.27 & 4.51 & 8.47 & 64.38 & 10.37 & 11.52 & 36.13 & \\
\hline SBM & 91.99 & 85.55 & 40.31 & 2.90 & 5.44 & 36.94 & 14.45 & 9.16 & 21.67 & \\
\hline MOL & 28.91 & 88.16 & 16.52 & 5.78 & 13.14 & 52.72 & 11.84 & 20.03 & 30.27 & \\
\hline WS & 94.43 & 79.68 & 2.66 & 1.85 & 33.62 & 41.55 & 20.32 & 49.61 & 77.26 & \\
\hline \multicolumn{11}{|c|}{ Rations: } \\
\hline $\mathrm{R}_{1}$ & 91.62 & 85.57 & 11.84 & 3.51 & 11.61 & 58.61 & 14.43 & 17.77 & 33.96 & 3.93 \\
\hline $\mathrm{R}_{2}$ & 88.04 & 85.64 & 11.03 & 3.64 & 11.99 & 58.98 & 14.36 & 18.34 & 34.19 & 3.93 \\
\hline $\mathrm{R}_{3}$ & 84.45 & 85.71 & 10.22 & 3.77 & 12.37 & 59.35 & 14.29 & 18.91 & 34.40 & 3.93 \\
\hline $\mathrm{R}_{4}$ & 77.27 & 85.85 & 8.60 & 4.03 & 13.12 & 60.10 & 14.15 & 20.04 & 34.83 & 3.93 \\
\hline
\end{tabular}

Table (3). Digestibility coefficients and nutritive values of the tested rations on DM basis.

\begin{tabular}{|c|c|c|c|c|c|}
\hline \multirow{2}{*}{ Item } & \multicolumn{4}{|c|}{ Tested rations } & \multirow{2}{*}{$\mathrm{SE}$} \\
\hline & $\mathrm{R}_{1}$ & $\mathrm{R}_{2}$ & $\mathrm{R}_{3}$ & $\mathrm{R}_{4}$ & \\
\hline \multicolumn{6}{|c|}{ Digestibility coefficients \%: } \\
\hline $\mathrm{DM}$ & 71.35 & 69.14 & 65.22 & 64.62 & 0.42 \\
\hline OM & 68.51 & 66.19 & 66.21 & 64.34 & 0.51 \\
\hline $\mathrm{CP}$ & 67.28 & 69.72 & 67.95 & 66.45 & 0.46 \\
\hline $\mathrm{EE}$ & $58.64^{\mathrm{b}}$ & $65.21^{\mathrm{a}}$ & $64.57^{\mathrm{a}}$ & $52.18^{\mathrm{c}}$ & 0.64 \\
\hline $\mathrm{CF}$ & 62.56 & 59.22 & 57.68 & 55.38 & 0.39 \\
\hline NFE & 72.63 & 73.29 & 70.37 & 67.94 & 0.52 \\
\hline \multicolumn{6}{|l|}{ Nutritive values: } \\
\hline TDN, $\%$ & $62.45^{\mathrm{a}}$ & $63.35^{\mathrm{a}}$ & $61.32^{\mathrm{b}}$ & $58.54^{\mathrm{c}}$ & 0.42 \\
\hline DE, Mcal/kg DM & $2.69^{\mathrm{a}}$ & $2.72^{\mathrm{a}}$ & $2.63^{\mathrm{b}}$ & $2.49^{c}$ & 0.03 \\
\hline DCP, $\%$ & $7.97^{\mathrm{a}}$ & $7.69^{a}$ & $6.94^{\mathrm{b}}$ & $5.70^{\mathrm{c}}$ & 0.07 \\
\hline
\end{tabular}


Table (4). Effect of moringa leaves on growth performance of fattening lambs.

\begin{tabular}{|c|c|c|c|c|c|}
\hline \multirow{2}{*}{ Item } & \multicolumn{4}{|c|}{ Rations } & \multirow{2}{*}{$\mathrm{SE}$} \\
\hline & $\mathrm{R}_{1}$ & $\mathrm{R}_{2}$ & $\mathrm{R}_{3}$ & $\mathrm{R}_{4}$ & \\
\hline Average initial weight, $\mathrm{kg}$ & 45.36 & 45.58 & 44.94 & 44.86 & 1.04 \\
\hline Average final weight, $\mathrm{kg}$ & 54.90 & 53.65 & 56.23 & 54.31 & 1.22 \\
\hline Total gain, $\mathrm{kg}$ & $9.54^{\mathrm{b}}$ & $8.08^{\mathrm{c}}$ & $11.29^{\mathrm{a}}$ & $9.45^{\mathrm{b}}$ & 0.18 \\
\hline Daily gain, $g$ & $106.00^{\mathrm{b}}$ & $89.72^{\mathrm{c}}$ & $125.42^{\mathrm{a}}$ & $105.00^{\mathrm{b}}$ & 3.07 \\
\hline \multicolumn{6}{|c|}{ Average daily feed intake/head: } \\
\hline $\mathrm{DM}, \mathrm{kg}$ & 1.35 & 1.39 & 1.44 & 1.52 & 0.09 \\
\hline TDN, kg & 0.84 & 0.88 & 0.88 & 0.89 & 0.03 \\
\hline DE, Mcal & 3.63 & 3.78 & 3.79 & 3.78 & 0.16 \\
\hline $\mathrm{DCP}, \mathrm{g}$ & $107.60^{\mathrm{a}}$ & $106.90^{\mathrm{a}}$ & $99.94^{\mathrm{b}}$ & $86.64^{c}$ & 2.97 \\
\hline \multicolumn{6}{|l|}{ Feed conversion: } \\
\hline DM/gain, kg/kg & $12.74^{\mathrm{b}}$ & $15.50^{\mathrm{a}}$ & $11.48^{\mathrm{c}}$ & $14.48^{\mathrm{a}}$ & 0.22 \\
\hline TDN/gain, kg/kg & $7.92^{\mathrm{b}}$ & $9.81^{\mathrm{a}}$ & $7.02^{c}$ & $8.48^{\mathrm{b}}$ & 0.40 \\
\hline DE/gain, Mcal/kg & $34.25^{\mathrm{b}}$ & $42.47^{\mathrm{a}}$ & $30.32^{\mathrm{c}}$ & $36.00^{\mathrm{b}}$ & 0.83 \\
\hline DCP/gain, g/g & $1.02^{\mathrm{b}}$ & $1.19^{\mathrm{a}}$ & $0.80^{\mathrm{c}}$ & $0.83^{\mathrm{c}}$ & 0.05 \\
\hline
\end{tabular}

Average in the same row having different superscripts are differ significantly $(P \leq 0.05)$

Table (5). Effect of moringa leaves supplements in the fattening lamb rations on some blood parameters.

\begin{tabular}{llllll}
\hline \multirow{2}{*}{ Item } & \multicolumn{3}{c}{ Rations } & \multirow{2}{*}{$\mathrm{SE}$} \\
\cline { 2 - 5 } & $\mathrm{R}_{1}$ & $\mathrm{R}_{2}$ & $\mathrm{R}_{3}$ & $\mathrm{R}_{4}$ & \\
\hline Total protein, g/dl & 4.07 & 4.33 & 4.47 & 4.50 & 0.09 \\
Albumin, g/dl & 2.67 & 2.97 & 3.17 & 3.20 & 0.13 \\
Globulin, g/dl & 1.40 & 1.37 & 1.30 & 1.30 & 0.05 \\
A/G ratio & $1.91: 1$ & $2.17: 1$ & $2.44: 1$ & $2.46: 1$ & 0.03 \\
Urea, mg/dl & $44.67^{\mathrm{a}}$ & $34.33^{\mathrm{b}}$ & $26.67^{\mathrm{c}}$ & $28.33^{\mathrm{c}}$ & 2.73 \\
Creatinine, mg/dl & 0.70 & 0.76 & 0.71 & 0.73 & 0.03 \\
AST,IU/l & $183^{\mathrm{a}}$ & $104^{\mathrm{c}}$ & $95^{\mathrm{c}}$ & $116^{\mathrm{b}}$ & 12.70 \\
ALT, IU/l & $45.33^{\mathrm{a}}$ & $26.00^{\mathrm{b}}$ & $21.00^{\mathrm{c}}$ & $21.33^{\mathrm{c}}$ & 4.61 \\
Sugar & 39.33 & 47.33 & 45.00 & 44.00 & 1.80 \\
\hline
\end{tabular}

Serum Aspartate aminotransferase (AST) and Alanin aminotransferase (ALT)

Average in the same row having different superscripts are differ significantly $(P \leq 0.05)$

Table (6). Economical evaluation of moringa leaves level in the rations.

\begin{tabular}{|c|c|c|c|c|}
\hline \multirow{2}{*}{ Item } & \multicolumn{4}{|c|}{ Rations } \\
\hline & R1 & $\mathrm{R} 2$ & R3 & $\mathrm{R} 4$ \\
\hline Total weight gain/head/period, kg & 9.54 & 8.08 & 11.29 & 9.45 \\
\hline Dry matter consumed/head/period, $\mathrm{kg}$ & 121.50 & 125.1 & 129.6 & 136.8 \\
\hline Price of one $\mathrm{kg}$ DM of the ration, L.E. & 1.96 & 1.85 & 1.74 & 1.52 \\
\hline Cost of feed consumed/head/period, L.E. & 238.14 & 231.44 & 225.5 & 207.94 \\
\hline Relative cost of feed consumed/head/ period & 100 & 97.19 & 94.69 & 87.32 \\
\hline Total revenue, L.E & 343.44 & 290.88 & 406.44 & 340.2 \\
\hline Net revenue, L.E & 105.3 & 59.44 & 180.94 & 132.26 \\
\hline Relative percentage of net revenue & 100 & 56.45 & 171.83 & 125.6 \\
\hline
\end{tabular}




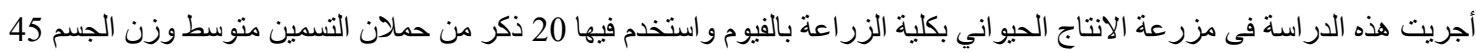

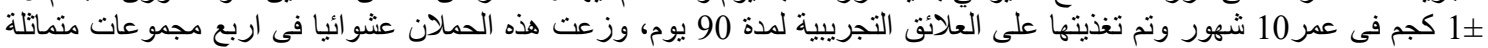

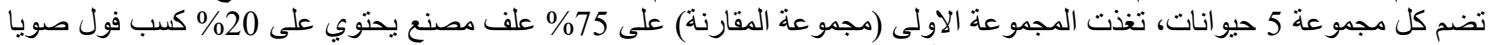

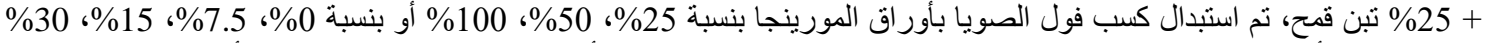

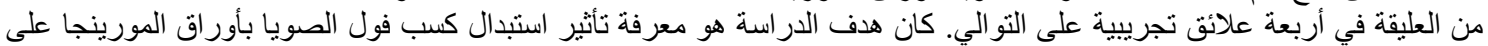

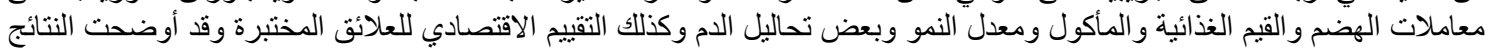

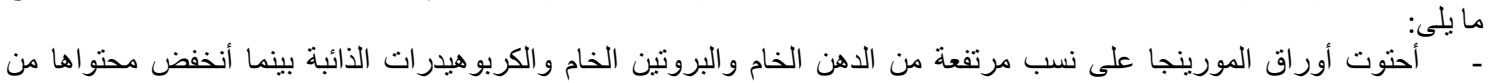

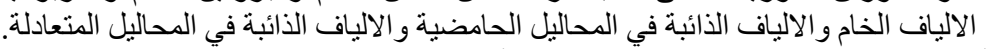

ـ ـ ـ أظهرت معاملات هضم المركبات المختلفة تأثير غير معنوي بين العلائق المختبرة فيما عدا الدهن الخام فاظهر تأثيرمعنوي لصالح العليقة الثانية و الثالثة.

لم يكن هناك أختلاف معنوي بين القيم الغذائية للطاقة نتيجة إضافة أوراق المورينجا للعليقة بينما أظهرت قيم البروتين المهضوم انخفاض معنوي بزيادة مستوي أوراق المبن المورينجا في العليقة.

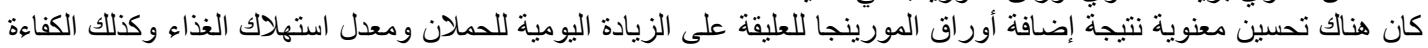
التحويلية للغذاء بزيادة مستوى أور اق المون المورينجا فى العليقة.

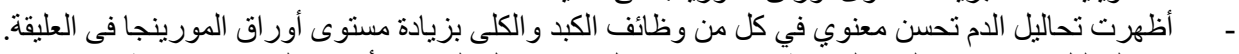

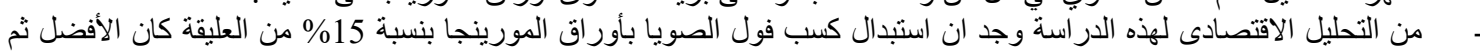

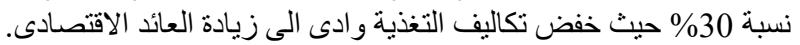

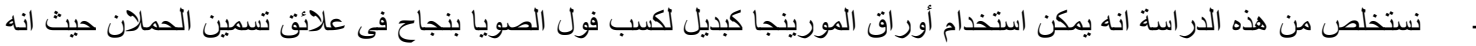
يقلل من استخدام كسب فول الصويا المرتفع فى ثمنه وبذلك يخفض من تكلفة العلائق ويؤدى الى زيادة العائد الاقتصادى. 